\title{
Precise Benefit Management: The Way to Solve The Black Hole Of Information Technology
}

\author{
Hongliang Wang ${ }^{1,2,3, a}$ \\ ${ }^{1}$ School of Administration and Business, Zhengzhou University of Aeronautics \\ ${ }^{2}$ Henan Cooperative Innovation Center For Aviation Economic Development \\ ${ }^{3}$ School of economics, Huazhong University of Science and Technology, Wuhan, Hubei, 430074 \\ ayes2001@zzia.edu.cn
}

Keywords: Black hole, Informationization, Precise benefit Management

\begin{abstract}
The paper analyses the profound reason of " black hole " of information technology in enterprise, puts forward the concept of precise benefit management. On the base of analyses the importance of precise benefit manage to enterprise, draw the conclusion that the business administration idea should be in conformity with the developing stage of information technology.
\end{abstract}

\section{Introduction}

According to relevant data, in the 1980s, the investment of U.S.A.'s informationization adds up to 1,000 billion dollars. Pushed by the information technology, the blue collar number reduce by $6 \%$, the output increase by $15 \%$, outwardly the labor productivity is raised by $15 \%$; however, the white collar's number grows up to $21 \%$, in fact the productivity drops by $6 \%$; Enterprises invest the information technology to feel and enter a deep black hole without seeing the bottom,which sounds like throwing the money. the phenomenon cause American society apply enterprise productivity thinking of paradox transformation produce to information technology; Initial stage of Informationization in the eighties in China, the information-based capital cost is up to 8 billion yuan, yet the success rate is less than 10\%[1] . A rate of increase survey report about U.S.A. which McKinsey made in 2001, find that only 6 in 59 trades' improvement of production efficiency are promote by investment on information technology.

In theory, utilize IT technology to improve business administration, increasing the benefit and efficiency, support enterprise's operation, control and decision. But the result of concrete practice is not the theory one, for many years after a lot of enterprises have put into a huge sum of money in informationization, but produce little effect, and some enterprise ERP can only make such simple application as some stock control ,etc. finally. And, the success rate that present domestic ERP implements is fewer than 20\%[2-3], enterprises have not realized the purpose of " appreciation " .

Enterprise is it reach anticipated goal to make the investment in IT use, opposite the productivity is it lower instead to rise in some cases, the enormous drop exists between informationalized input and output of the informationization. the economist calls this kind of drop " the productivity paradox ", some experts call this kind of phenomenon " the black hole of IT ", because the investment of the information technologies can be included in the category of enterprise's informationization, we calls that enterprise's informationization " black hole " question. In the information-based process, " black hole " keeps engulfing limited and valuable resources of enterprise, the ones that made the dream in entrepreneur's brain often change are out of reach.

A lot of domestic scholars have carried on research to this phenomenon and reason caused, have put forward a lot of different views and solutions of pertinence[4]. The view of the domestic scholar of survey, think " black hole " reason is as follows: (1). Administration and supervision authorities and information-based executive lack unified understanding and understanding to the informationization;(2).Enterprise's demand is indeterminate, lack systematic thought, ERP products and demand mismatch that are chosen;(3). Not so connected as the information-based strategy related to management strategy of enterprises; (4). ERP supplier that enterprise choose is it is it is it implement professional advisory agent's service ability, ERP of experience to succeed in 
to have to lack; (5).Enterprises have not got the basic data that the informationization needs ready, the element task has not kept up with ; (6).Have not changed enterprise's existing management mode and method ; (7). It is not enough to lack ERP and implement strength or dynamics, choose the suitable products, but suitable person does not implement; (8).Lacking effective implementation to manage, it is wayward, apt to cause ERP to miscarry midway to implement the progress.

Research the answer black hole production reason and enterprise should diligent direction to a certain extent, but there is still a limitation in some aspects, for instance equate the informationization with the implementation of ERP, not explaining the reason of the black hole phenomenon from profound level, this text attempts to seek the origin that the information-based black hole appears in term of evolving in information technology.

\section{Three Stages of the Information Technology and Profound Reason of the Information-based Black Hole}

Exception of the Information-based Black Hole. Though the informationization of a lot of enterprises has fallen into the predicament of losing more than gain, in a lot of trades, for example global the civil aviation, insure in the trade, banking, retail business, train traffic, industry design trade, the informationization has brought the improvement of unexpected productivity, utilize the information technology to reduce the error, improve quality, lower costs and solve the problem of key bottleneck done by hand. The exceptional phenomenon of and the informationization " black hole ", with the constant development of the technology and society, have the tendency to popularize gradually.

Three Application Stages of the Information Technique. Considering these questions synthetically, according to the view of the scholar (such as Shoshana\&Zuboff ) [5], the application of the information technology can be divided into three stages, namely: Automatic stage, information management stage and Business transformation. Range of application, interests, influence brought at each stage are different from capital of requisition for personnel's quality, can be proved by the Table.1[5-6].

With the help of this theory, we can explain a lot of information-based black hole questions . Trade and field of making the informationization and succeeding mostly belong to first application stage of information technical --At automatic stage of work, the requisition for enterpri-se personnel especially administrator is lower at this stage. In informationalized advanced stage, especiallly application of ERP, a lot of enterprises , especially manufacturing industries have often presented " black hole " phenomenon; At the same time, we can find out, the average quality of those staff is higher and organizing the learning ability to be strong, managing new-type enterprises with leading idea, has made relative success in the application of e-commerce, namely: It is apteral to present the exceptional phenomenon of the informationization " black hole ".

Profound reason of the black hole. In fact, each stage of information technical development, require management level and environment of an enterprise to vary with it. Automatic stage of work, information technology application including such as basic data calculate, salary calculate and deal with orders, automatic activity of work of booking tickets etc. for the first time in commerce. The application of the information technology is mainly to bring the improvement of operating efficiency, the course that this kind of application has replaced a large amount of human repetition and worked. From dealing with it to automation artificially, the procedure change of transaction processing is not big during that time. So at this stage, the informationization is pates to succeed. 
Table 1 Three application stages of the information technique

\begin{tabular}{|l|l|l|l|l|}
\hline \multicolumn{1}{|c|}{ Stage } & \multicolumn{1}{|c|}{ Influence } & \multicolumn{1}{c|}{ benefits } & \multicolumn{1}{c|}{$\begin{array}{c}\text { Requisition for } \\
\text { personnel }\end{array}$} & \multicolumn{1}{c|}{ examples } \\
\hline $\begin{array}{l}\text { Automatic } \\
\text { stage }\end{array}$ & $\begin{array}{l}\text { Finish the work } \\
\text { The high-efficiency } \\
\text { one does the same } \\
\text { thing }\end{array}$ & $\begin{array}{l}\text { Efficiency } \\
\text { operated }\end{array}$ & $\begin{array}{l}\text { The staff master } \\
\text { certain IT } \\
\text { technology }\end{array}$ & $\begin{array}{l}\text { The staff manage } \\
\text { salary } \\
\text { Payment system of } \\
\text { the bank } \\
\text { Book tickets in } \\
\text { aviation }\end{array}$ \\
\hline $\begin{array}{l}\text { Information } \\
\text { management }\end{array}$ & $\begin{array}{l}\text { Work and } \\
\text { workflow are } \\
\text { predominated The } \\
\text { one out of the } \\
\text { common does } \\
\text { things }\end{array}$ & $\begin{array}{l}\text { Validity of } \\
\text { operating } \\
\text { and tactics }\end{array}$ & $\begin{array}{l}\text { The staff should not } \\
\text { only master } \\
\text { technology to but } \\
\text { also need to } \\
\text { establish the } \\
\text { information idea }\end{array}$ & $\begin{array}{l}\text { information } \\
\text { management } \\
\text { system } \\
\text { Aviation } \\
\text { administrative } \\
\text { system Manager's } \\
\text { information system }\end{array}$ \\
\hline $\begin{array}{l}\text { Business } \\
\text { transformation }\end{array}$ & $\begin{array}{l}\text { Define the } \\
\text { commerce to } \\
\text { manage } \\
\text { Do different things } \\
\text { Change the } \\
\text { commerce / } \\
\text { industry's rule }\end{array}$ & $\begin{array}{l}\text { The } \\
\text { validity of } \\
\text { strategy } \\
\text { and } \\
\text { strategy } \\
\text { reservation }\end{array}$ & $\begin{array}{l}\text { The staff should } \\
\text { possess very strong } \\
\text { information idea and } \\
\text { working skill }\end{array}$ & $\begin{array}{l}\text { JiT } \\
\text { E-commerce } \\
\text { system } \\
\text { ERP }\end{array}$ \\
\hline
\end{tabular}

At information management stage, as a large amount of information produced in the working course of automation, the focal point at this stage is to transform from improving the work efficiency to improving the enterprise's operating and tactics result. The appearance of the network bank redefines financial circles, have reduced the obstacle entered and reducing the demarcation line between the financial products. The online bookstore redefines the publishing business and adjust many kinds of methods of service of the new business. At this stage, the missions of enterprises are to improve, need to manage the transition of the idea, change the industrial structure and industry's operation rule.

For example: While using CRM in the financial trade, employee must study new skill, establish new sense of responsibility and accept different remuneration system. To the bank customer, need accurate relevant information of explanation, train the personal relation, but not fast treatment trade and routine answer the problem.

From the above-mentioned analysis, The profound reason of the information-based black hole is the misplacing of information technology stage between the management ideas of enterprises, its own staff's quality and manage stage basically. When the business administration idea lags behind the developing stage of information technology, the enterprises Often become profitless in informationalized input.

The large quantities of traditional enterprises of our country develop and face a lot of realistic problems at present, for example, capital source, management level, research and development ability, Chinese government has issued the strategy of " driving industrialization and taking the new-type industrialized road with the informationization " too. In order to improve informationalized success rate, dispel " black hole " phenomenon, We should operate fine enterprise operation course informationization, make management idea and staff quality of enterprise catch up with developing stage in information technology, in this way, we can reduce the probability that the informationization " black hole " appear . 


\section{Precise Benefit Managment}

Definition of Precise Benefit Management. Precise benefit management idea stemming from the lean production, some management scholars of the USA and Europe summarize and propose and deepen on the basis of excavating Japanese Toyota and managing management mode thoroughly. It require that rejects the waste of all forms continuously while all is systematic, each action of improving the procedure and adopting in the course of production of precise benefit, all through planning, carrying out and assessing according to the total goal of the system, it not only merely reflects in production, but also reflect in including of the a series of procedure in quality control, maintain , assess, etc., Precise benefit manage thought form a whole set of combine precise benefit performance of corporate culture already. No matter the level of the scale of enterprises , specialized skill level of engineering level or the staff member .

In more than 10 years in the past, the USA and Europe has introduced and digests it in the precise benefit thought and management practice innovating, according to the investigations of this ,people find the mode of production of smart benefit especially precise benefit thought reflected among them are generally suitable. It can be suitable for any economic mode, in any manufacturing industry or the service trade company. It is a kind of inevitable choice if the enterprise wanted to develop better under a fiercer environment in economic globalization, demand pluralism and competition .

Overall Principle of the Precise Benefit Management System. Precise benefit marrow of ideological system can summarize as five basic principle, and the five basic principle prove precise benefit thought have extensive general getting right theoretical foundation too.

(1)Define value accurately, and value can only be confirmed by the end user, We should regard customer as the centre to confirm value instead of regarding enterprise oneself as the centre, make customer's demand maximize, enterprises should establish this thought at the beginning when it is channeling into information-based project. (2)Discern the value of enterprises flows according to user's value. The focus of enterprise's competition is how to make use of scale advantage of the industrial society and the low cost advantage of the information-intensive society to meet customer's individualized demand. At this time, the value structure of the products was confirmed by the customer. (3)Let the value of enterprises flowing. The meaning of " flowing " is to say " the value appreciation incessantly ". Proceed from this angle, " group by group ", " line up ", " stock " should be regarded as the improved target, we should pay close attention to such as: the punctuality inside enterprises (JIT) and the punctuality among related enterprises (the idea of supply chain management), profound course of business process reengineering, the group organized and does away with a hierarchical system, the managing live of the workshop etc. (4)Spur value to " pull " with the user's needs. Enterprise should draw movable production according to customer's demand, but not often push the products that the customer does not want hardly to customers. (5)Pursue the perfection forever. The glamour of precise benefit with eternal thought lies in being never complacent and pursuing the perfection. Standard working routine and encouraging system constructed on the basis of the precise benefit idea. Promote enterprises challenge ideal limit and never stop acting on one's own. The precise benefit thought has described reservation of value, essential feature and direction of new-type enterprises with the value, value flows, flowing, pulling, perceptions principles. It has announced the essential intension of the factor that a lot of keys for succeeding in enterprise's competition at present.

Concrete Implementation in the Information-based Course of Precise Benefit Management. The Leaders should Pay Attention to the Infiltration of the Precise Benefit Idea. The application range of the precise benefit thought has already been transferred from the initial production process to each trade, each link, the leaders of enterprises should establish a kind of thought which is good at study first, examine every department of enterprises, every course closely, channel into the thought of precise benefit management firmly, improve, optimize the basic management. Utilize all chances at the same time, train the cadres and workers at all levels of enterprises, inculcate such new management idea to them. Only this thought becomes the unconscious guide to all actions of enterprises, the basic management of enterprises can just reach the optimum state, the success rate 
of information application in enterprises will be taller, the phenomenon of the information-based black hole will be more easier to avoid .

Paid attention to the ordinary staff's behavior and the forming process. Precise benefit thought start from paying attention to every detail, so enterprise should pay attention to ordinary staff to form good behavior, including: Good at studying new knowledge , improving the workflow , production technology with the precise benefit thought, dispel all invalid work, reduce energy consumption. Only in this way, informationalized obstruction will just be minimum , the efficiency made after the informationization will just be the biggest.

\section{Conclusion}

The informationization can bring the improvement of operation efficiency to enterprise, make enterprises obtain the relative competition advantage, but the management ideas of enterprises, staff's quality, basic management must meet the stage of the information technical development , otherwise, the information-based black hole phenomenon is difficult to avoid. The idea of precise benefit management is a kind of brand-new management idea, it strengthen basic management to enterprises, improve the performance of managing, thus settle good foundation for implementing the informationization in an all-round way in enterprises. At present, as China is being deepened constantly opening to the outside world, enterprises are in the face of the competition that is globalized; Introduce the idea of precise benefit management in time will contribute to succeeding in implementing the informationization, thus improve the international competitiveness .

\section{Acknowledgements}

This work is supported by National Social Science Fund (14BJL004) ;Aerospace Science Foundation of China under Grant 2015ZG55022; Soft science project of Henan provincial science and Technology Department.

\section{References}

[1] ZHOU GUI-mei, The Analysis of the Reasons for "Black Hole" in Enterprises' informatization,Shandong University at Weihai,COMMERCIAL RESEARCH, Apr.2014

[2] Brian J.Carrall. Lean performance ERP Project Management-Implementing the Virtual Supply Chain. St Lucic Press,May.2012.

[3] Wang Zhiwei, On lean Operation Philosophy and Its Practice, Journal of Liaoning University (Philosophy and Social Sciences Edition) ,July.2012

[4] BiXinhua,LiNa,Total Strategy Frame of Benefit Studying of Enterprise s Informationization Construction and Precise Innovation,Management College of Jilin University,Changchun,Jan.2004

[5] JiangRonghan.JiGuoli, An Access for Digitalization of Enterprises, JOURNAL OF WUT (INFORMATION \&MANAGEMENT ENGINEERING),Feb.2008

[6] John thorp (Canada) and DMR'S Center for Strategic Leadership, The Information Paradox, DongBei University of Finance\&Economics Press and McGraw-Hill Book Co,1999 